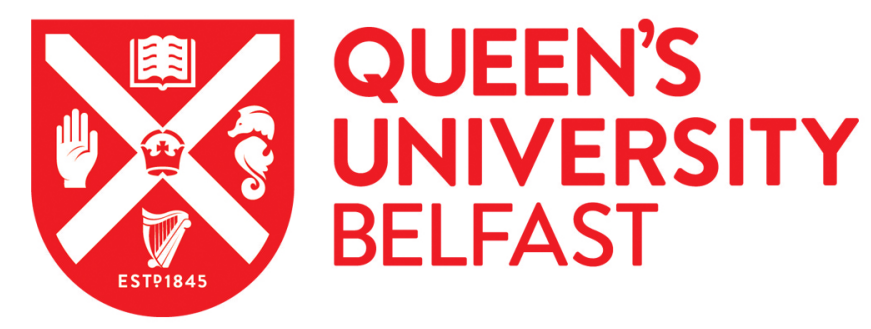

\title{
Metformin use and survival from lung cancer: a population-based cohort study
}

McMenamin, U., Cardwell, C., Hughes, C., \& Murray, L. (2016). Metformin use and survival from lung cancer: a population-based cohort study. Lung Cancer, 94, 35-39. https://doi.org/10.1016/j.lungcan.2016.01.012

\section{Published in:}

Lung Cancer

\section{Document Version:}

Peer reviewed version

Queen's University Belfast - Research Portal:

Link to publication record in Queen's University Belfast Research Portal

\section{Publisher rights}

Copyright $\odot 2016$ Elsevier Ireland Ltd. This manuscript is distributed under a Creative Commons Attribution-NonCommercial-NoDerivs License (https://creativecommons.org/licenses/by-nc-nd/4.0/), which permits distribution and reproduction for non-commercial purposes, provided the author and source are cited.

\section{General rights}

Copyright for the publications made accessible via the Queen's University Belfast Research Portal is retained by the author(s) and / or other copyright owners and it is a condition of accessing these publications that users recognise and abide by the legal requirements associated with these rights.

\section{Take down policy}

The Research Portal is Queen's institutional repository that provides access to Queen's research output. Every effort has been made to ensure that content in the Research Portal does not infringe any person's rights, or applicable UK laws. If you discover content in the Research Portal that you believe breaches copyright or violates any law, please contact openaccess@qub.ac.uk. 
Metformin use and survival from lung cancer: a population-based cohort study

\section{Authors:}

Úna C. Mc Menamin ${ }^{1}$, Chris R. Cardwell ${ }^{1}$, Carmel M. Hughes ${ }^{2}$, Liam M. Murray ${ }^{1,3}$.

\section{Affiliations:}

${ }^{1}$ Cancer Epidemiology and Health Services Research Group, Centre for Public Health, Queen’s University Belfast, Belfast, Northern Ireland.

${ }^{2}$ School of Pharmacy, Queen’s University Belfast, Northern Ireland, BT9 7BL.

${ }^{3}$ Centre of Excellence for Public Health (NI), Centre for Public Health, Queen’s University Belfast, Belfast, Northern Ireland, UK.

\section{Corresponding Author:}

Dr Úna Mc Menamin

Mail: Centre for Public Health, Institute of Clinical Sciences Block B, Queen’s University Belfast, Royal Victoria Hospital, Grosvenor Road, Belfast, BT12 6BA, Northern Ireland Phone: $+44(0) 2890633956$.

Fax: $+44(0) 2890635900$

E-mail: $\underline{\text { u.mcmenamin@qub.ac.uk }}$

\section{Abstract word count: 222}

Manuscript word count: 1,472

\section{Number of tables and figures: 2}

Abbreviations: BMI, body mass index; CIs, confidence intervals; CPRD, Clinical Practice Research Datalink; DDD, daily defined dose; GP, general practitioner; HR, hazard ratio; NCDR, National cancer Data Repository; ONS, Office of National Statistics; UK, United Kingdom; WHO, World Health Organisation. 


\section{Abstract}

Preclinical evidence suggests that metformin, a widely prescribed anti-diabetic drug, may inhibit lung cancer progression. We investigated whether metformin use was associated with decreased risk of cancer-specific mortality in lung cancer patients. This study included newly diagnosed lung cancer patients (identified from English National Cancer Data Repository, 1998-2009) with type 2 diabetes (based on UK Clinical Practice Research Datalink prescriptions and diagnosis records). Lung cancer deaths occurring up to 2012 were identified using Office of National Statistics mortality data and the association between metformin use (before and after diagnosis) and risk of lung cancer-specific mortality was calculated using Cox regression models. In analysis of 533 patients, we found a weak non-significant reduction in lung cancer-specific mortality with metformin use after diagnosis (adjusted HR, 0.86; 95\% CI, 0.68-1.09). No association was evident for metformin use before diagnosis and cancer-specific mortality in analysis of 1,350 patients (adjusted HR, 0.97; 95\% CI, 0.86, 1.11). Associations were similar by duration of use. In addition, after adjustment for potential confounders, there was little evidence of an association between the use of other anti-diabetic medications (either before or after diagnosis) and lung cancer-specific mortality; including sulfonylureas, insulin or other anti-diabetic medications (such as thiazolidinediones). Overall, the results from this population-based study provide little evidence of a protective association between metformin use and cancer mortality in lung cancer patients.

Keywords: metformin; lung cancer survival; pharmacoepidemiology; CPRD 


\section{Introduction}

Emerging evidence from preclinical studies suggests a potential antitumour effect for metformin, a biguanide derivative commonly prescribed to treat type 2 diabetes, possibly due to the activation of AMP-activated protein kinase, leading to the inhibition of the mTOR signalling pathway [1]. Metformin use has been associated with improved survival in patients with diabetes with breast [2], colorectal [3] and prostate cancer [4]; however there are limited data in lung cancer patients. Constitutive mTOR signaling plays an important role in the development of lung cancer and in vitro and animal studies have reported antiproliferative effects [5] and proapoptotic effects [6], as well as the inhibition of lung tumour growth [7]. Few epidemiological studies have assessed the influence of metformin on lung cancer-specific outcomes after diagnosis. Some, but not all [8] have reported improvements in progressionfree survival [9] and disease-free survival $[10,11]$ but these investigations were limited by small sample sizes [8-11], drug exposure determined at limited numbers of time-points [8-11] and a lack of adjustment for important baseline patient characteristics [9]. Other studies have investigated metformin use and overall survival [12-14], but these results could reflect mortality from non-cancer causes.

In this population-based study, we investigate for the first time the impact of metformin use, either before or after diagnosis, on lung cancer-specific survival. Secondary analysis investigated the influence of other anti-diabetic medications.

\section{Materials and Methods}

\subsection{Study design}


As described previously [15], we utilised record linkages between the English National Cancer Data Repository (NCDR) and the United Kingdom (UK) Clinical Practice Research Datalink (CPRD) to identify lung cancer patients diagnosed between 1998 and 2009. Office of National Statistics (ONS) mortality data provided deaths up to 2012. We restricted the cohort to those with a prior diagnosis of type 2 diabetes (based on a GP diagnosis of diabetes or at least one anti-diabetic medication prescription). Patients with type 1 diabetes were excluded and were defined as those with a diagnosis of type 1 diabetes in addition to at least one prescription for insulin before their cancer diagnosis. Patients were also excluded if they had a previous cancer (with the exception of non-melanoma skin cancers) or if their diagnosis date preceded CPRD research quality records. Ethical approval for all observational studies conducted using CPRD data has been obtained from a multicentre research ethics committee.

\subsection{Exposure data}

Data on post-diagnostic anti-diabetic medication usage was determined from general practitioner (GP) prescribing records contained within the CPRD according to the British National Formulary (BNF) [16] including metformin, sulfonylureas, insulin or other antidiabetic medications (including thiazolidinediones).

\subsection{Covariates}

The NCDR provided clinical data on tumour histology and receipt of cancer treatments including surgery, chemotherapy and radiotherapy. Information on lifestyle factors before diagnosis including smoking, alcohol and BMI was obtained from CPRD records. Comorbidities prior to diagnosis were derived from GP records and included those within a 
recent adaptation of the Charlson Comorbidity index [17]. A measure of deprivation was available from CPRD records [18]. Other medications including low-dose aspirin and statins were determined from GP-prescription records. Haemoglobin A1c (HbA1c) levels in the year prior to diagnosis were obtained from GP records.

\subsection{Statistical analysis}

\subsubsection{Statistical analysis for anti-diabetic medication use after diagnosis}

The analysis of drug use after diagnosis used Cox regression models to produce unadjusted and adjusted hazard ratios (HR) and 95\% confidence intervals (CI) for the association between antidiabetic medication usage and lung cancer-specific mortality. Patients that died in the first 6 months after diagnosis were removed as drug use during this time is unlikely to exert an effect on cancer death. Drug use was treated as time-varying [19], and was lagged by 6 months to remove prescriptions immediately prior to death (as these may reflect end-of-life care). Doseresponse relationships were investigated for metformin use by increasing number of prescriptions and defined daily doses (DDDs), as defined by the WHO [20]. Sub-group analyses for metformin use and lung cancer mortality were carried out by pre-diagnostic drug use and tumour histology. Separate sensitivity analyses additionally adjusted for smoking and HbA1c level (among individuals with available information) and type 2 diabetes duration (among individuals with at least 5 years of records before diagnosis).

\subsubsection{Statistical analysis for anti-diabetic medication use before diagnosis}

Cox regression models were utilised to calculate unadjusted and adjusted HRs and 95\% CIs for the association between anti-diabetic medication usage in the year prior to diagnosis and lung 
cancer-specific mortality. Patients with less than 1 year of CPRD records prior to diagnosis were removed. Similarly, dose-response relationships for metformin use were examined. Sensitivity analyses additionally adjusted for smoking, HbA1c level and type 2 diabetes duration.

\section{Results}

\subsection{Patient cohort}

A total of 1,443 lung cancer patients with diabetes were identified. The analysis of anti-diabetic medication use after diagnosis included 533 patients, after 910 patients with less than 6 months follow-up were excluded. The analysis of anti-diabetic medication use before diagnosis included 1,350 patients, after 93 patients with less than 1 year of records prior to diagnosis were excluded. Patient characteristics by metformin use are listed in Table 1. Users were more likely to be diagnosed more recently, be younger, be obese, to have had surgery and chemotherapy and to be users of statins and other anti-diabetic medications (except insulin). Some comorbidities were less common in users of metformin after diagnosis, Table 1.

\subsection{Association between anti-diabetic medication use after diagnosis and survival}

The results for the association between anti-diabetic medication use after diagnosis and survival are presented in Table 2. Metformin use after diagnosis was weakly associated with a reduction in lung cancer death, however, after adjustment for potential confounders, results attenuated (adjusted HR 0.86, 95\% CI 0.68-1.09) and there was no significant dose-response relationship by increasing number of prescriptions or DDDs. In sub-group analyses, results were similar after stratification by pre-diagnostic metformin use (non-users: adjusted HR 0.71, 95\% CI 0.45-1.13; users: adjusted HR 0.83, 95\% CI 0.41-1.69, $p$ for interaction=0.52) and tumour histology (small cell lung cancer: adjusted HR 0.61, 95\% CI 0.23-1.60; non-small cell 
lung cancer: adjusted HR 0.85, 95\% CI 0.63-1.14), $p$ for interaction=0.87). Additional adjustment for other factors did not materially alter effect estimates, including smoking (adjusted HR 0.86, 95\% CI 0.68-1.10), HbA1c level (adjusted HR 0.88, 0.68-1.13) and diabetes duration (adjusted HR 0.82, 95\% CI 0.62-1.10).

There was no evidence of an association for sulfonylurea or insulin use. There was a suggestion of an increased risk of cancer mortality with the use of other anti-diabetic medication (including thiazolidinediones); but analysis was not significant and based on only 45 users (adjusted HR 1.42, 95\% CI 0.94-1.13).

\subsection{Association between anti-diabetic medication use before diagnosis and survival}

No association between metformin use prior to diagnosis and lung cancer-specific mortality was observed and no dose-response association was apparent, Table 2. The findings remained largely unchanged after additional adjustment for smoking, HbA1c level and type 2 diabetes duration (data not shown). Sulfonylurea, insulin and other anti-diabetic medication use were not associated with cancer-specific mortality, Table 2.

\section{Discussion}

Using population-based data, we observed a $14 \%$ non-significant reduction in cancer-specific mortality with metformin use after diagnosis in a large cohort of lung cancer patients with preexisting type 2 diabetes, however this reduction was weak in magnitude and there was no clear evidence of a dose-response association.

No study has investigated the influence of metformin use on cancer-specific survival in a cohort of lung cancer patients. Inconsistent with our findings, two previous studies reported significant reductions in all-cause mortality in users of metformin before [13] or after [14] lung cancer 
diagnosis. A further study reported a shorter overall survival in pre-diagnostic metformin users compared to non-users [12]. Unlike our investigation, previous studies did not investigate dosedependent relationships [12-14] and metformin use after diagnosis was time-fixed [14], thus potentially introducing immortal time bias. Moreover, results from studies investigating allcause mortality could be reflective of non-cancer mortality.

Strengths of this study included an unselected lung cancer cohort and record linkages between NCDR and ONS data, allowing for robust verification of cancer diagnoses and deaths. Highquality GP prescribing data [21] eliminated any recall bias and allowed for temporal associations to be examined. Furthermore, we provided an inclusive and simultaneous examination of all anti-diabetic medications and risk of lung cancer-specific mortality. The present study is the largest to investigate metformin use and outcomes after lung cancer diagnosis; however, a lack of statistical power in sub-group analyses is possible. Although we did not have information on medication compliance, it is unlikely that this is affecting our results because similar findings were observed in dose-response analyses. We were also unable to adjust for cancer stage, thus potentially introducing residual confounding.

\section{Conclusion}

In conclusion, the results from this novel population-based study provide little evidence that metformin use is associated with increased lung cancer survival. Further investigation in larger sample sizes is required to verify these findings. 
Conflict of interest statement: The authors declared no conflict of interest.

Financial support: CRC and ÚMM were supported by a Health and Social Care Research and Development, Public Health Agency, Northern Ireland, funded UK NIHR Career Development Fellowship, which also funded access to the CPRD dataset.

Acknowledgments: This study is based in part on data from the Clinical Practice Research Datalink obtained under licence from the UK Medicines and Healthcare products Regulatory Agency. However, the interpretation and conclusions contained in this study are those of the authors alone. 


\section{References}

1. Dowling RJO, Goodwin PJ, Stambolic V. Understanding the benefit of metformin use in cancer treatment. BMC Med 2011; 9:33.

2. Vissers PAJ, Cardwell CR, van de Poll-Franse LV, Young IS, Pouwer F, Murray LJ. The association between glucose-lowering drug use and mortality among breast cancer patients with type 2 diabetes. Breast Cancer Res Treat 2015;150:427-37.

3. Garrett CR, Hassabo HM, Bhadkamkar NA, Wen S, Baladandavuthapain V, Kee BK, Eng C, Hassan MM. Survival advantage observed with the use of metformin in patients with type II diabetes and colorectal cancer. Br J Cancer 2012;106:1374-8.

4. Margel D, Urbach DR, Lipscombe LL, Bell CM, Kulkarni G, Qustin PC, Fleshner N. Metformin use and all-cause and prostate cancer-specific mortality among men with diabetes. J Clin Oncol 2013;31:3069-75.

5. Storozhuk Y, Hopmans SN, Sanli T, Barron C, Tsiani E, Cutz JC, Pond G, Wright J, Singh G, Tsakiridis T. Metformin inhibits growth and enhances radiation response of non-small cell lung cancer (NSCLC) through ATM and AMPK. Br J Cancer 2013; 108:2021-31.

6. Wu N, Gu C, Gu H, Hu H, Han Y, Li Q. Metformin induces apoptosis of lung cancer cells through activating JNK/p38 MAPK pathway and GADD153. Neoplasma 2011;58:482-490.

7. Memmott RM, Mercado JR, Maier CR, Kawabata S, Fox SD, Dennis PA. Metformin prevents tobacco carcinogen--induced lung tumorigenesis. Cancer Prev Res 2010; 3:1066-76. 
8. Ahmed I, Ferro A, Cohler A, Langenfeld J, Surakanti SG, Aisner J, Zou W, Haffty BG, Jabbour SK. Impact of metformin use on survival in locally-advanced, inoperable non-small cell lung cancer treated with definitive chemoradiation. J Thorac Dis 2015;7:346-55.

9. Tan BX, Yao WX, Ge J, Peng XC, Du XB, Zhang R, Yao B, Xie K, Li LH, Dong H, Gao F, Zhao F, Hou JM, Su JM, Liu JY. Prognostic influence of metformin as firstline chemotherapy for advanced nonsmall cell lung cancer in patients with type 2 diabetes. Cancer 2011; 117:5103-11.

10. Xu T, Liang, G, Yang, L, Zhang F. Prognosis of small cell lung cancer patients with diabetes treated with metformin. Clin Transl Oncol 2015 [Epub ahead of print].

11. Kong F, Gao F, Liu H, Chen L, Zheng R, Yu J, Li X, Liu G . Metformin use improves the survival of diabetic combined small-cell lung cancer patients. Tumour Biol 2015 [Epub ahead of print].

12. Mazzone PJ, Rai H, Beukemann M, Xu M, Jain A, Sasidhar M. The effect of metformin and thiazolidinedione use on lung cancer in diabetics. BMC Cancer 2012;12:410.

13. Lin JJ, Gallagher EJ, Sigel K, Mhango G, Galsky MD, Smith CB, LeRoith D, Wisnivesky JP. Survival of patients with stage IV lung cancer with diabetes treated with metformin. Am J Respir Crit Care Med 2015; 191:448-54.

14. Currie CJ, Poole CD, Jenkins-Jones S, Gale EA, Johnson JA, Morgan CL. Mortality after incident cancer in people with and without type 2 diabetes: impact of metformin on survival. Diabetes Care. 2012; 35:299-304. 
15. Cardwell CR, Mc Menamin Ú, Hughes CM, Murray LJ. Statin use and survival from lung cancer: a population-based cohort study. Cancer Epidemiol Biomarkers Prev 2015; 24:833-41.

16. British National Formulary 66th ed. 2013. Joint Formulary Committee. London, UK: BMJ Group and Pharmaceutical Press.

17. Khan NF, Perera R, Harper S, Rose PW. Adaptation and validation of the Charlson Index for Read/OXMIS coded databases. BMC Fam Pract 2010; 11:1.

18. Noble M, Wright G, Dibben C, et al. Indices of deprivation 2004: Report to the office of the deputy prime minister. London, UK, Neighb Renew Unit. 2004.

19. Lévesque LE, Hanley JA, Kezouh A, Suissa S. Problem of immortal time bias in cohort studies: example using statins for preventing progression of diabetes. Br Med J 2010; 340:907-911.

20. World Health Organisation: World Health Organisation Collaborating Centre for Drug Statistics Methodology. Available from: http://www.whocc no/.

21. Jick H, Jick SS D LE. Validation of information recorded on general practitioner based computerised data resource in the United Kingdom. Br Med J 1991;302:766-8. 
Table 1. Characteristics of lung cancer patients by metformin use

\begin{tabular}{|c|c|c|c|c|c|c|}
\hline \multirow{2}{*}{ Characteristics } & \multicolumn{2}{|c|}{$\begin{array}{l}\text { Metformin use in year prior } \\
\text { to diagnosis }{ }^{\text {a }}\end{array}$} & \multicolumn{2}{|c|}{$\begin{array}{c}\text { Metformin use in year after } \\
\text { diagnosis }^{b}\end{array}$} & \multicolumn{2}{|c|}{$\begin{array}{c}\text { Metformin use after } \\
\text { diagnosis }^{b}\end{array}$} \\
\hline & $\begin{array}{c}\text { User n } \\
(\%)\end{array}$ & $\begin{array}{c}\text { Non-user n } \\
(\%)\end{array}$ & $\begin{array}{c}\text { User n } \\
(\%)\end{array}$ & $\begin{array}{c}\text { Non-user n } \\
(\%)\end{array}$ & $\begin{array}{c}\text { User n } \\
(\%)\end{array}$ & $\begin{array}{c}\text { Non-user n } \\
(\%)\end{array}$ \\
\hline & \multicolumn{2}{|c|}{$(n=1,350)$} & \multicolumn{2}{|c|}{$(n=533)$} & \multicolumn{2}{|c|}{$(n=533)$} \\
\hline Year of diagnosis: $1998-2000$ & $45(7)$ & $108(16)$ & $25(9)$ & $39(16)$ & $23(9)$ & $41(15)$ \\
\hline 2001-2003 & $113(17)$ & $163(24)$ & $33(12)$ & $57(23)$ & $29(12)$ & $61(22)$ \\
\hline $2004-2006$ & $175(26)$ & $191(28)$ & $84(30)$ & $58(23)$ & $71(28)$ & $71(25)$ \\
\hline 2007-2009 & $331(50)$ & $224(33)$ & $141(50)$ & $96(38)$ & $128(51)$ & 109 (39) \\
\hline Age at diagnosis: $<50$ & $1(0)$ & $8(1)$ & $0(0)$ & $7(3)$ & $0(0)$ & $7(2)$ \\
\hline $50-59$ & $57(9)$ & $57(9)$ & $33(12)$ & $12(5)$ & $30(12)$ & $15(5)$ \\
\hline $60-69$ & $183(28)$ & $183(28)$ & $90(32)$ & 67 (27) & $81(32)$ & $76(27)$ \\
\hline $70-79$ & $286(43)$ & $286(43)$ & $116(41)$ & $109(44)$ & $104(41)$ & $121(43)$ \\
\hline $80-89$ & $130(20)$ & $130(20)$ & $43(15)$ & $54(22)$ & $35(14)$ & $62(22)$ \\
\hline$\geq 90$ & $7(1)$ & $7(1)$ & $1(0)$ & $1(0)$ & $1(0)$ & $1(0)$ \\
\hline Gender: Males & $437(66)$ & $445(65)$ & $190(67)$ & $153(61)$ & $174(64)$ & $169(65)$ \\
\hline \multicolumn{7}{|c|}{ Treatment within 6 months of cancer diagnosis } \\
\hline Surgery ${ }^{c}$ & $77(15)$ & $47(9)$ & $71(32)$ & $26(13)$ & $67(33)$ & $30(14)$ \\
\hline Chemotherapy & $153(23)$ & $100(15)$ & $100(35)$ & $69(28)$ & $90(36)$ & $79(28)$ \\
\hline Radiotherapy & $182(27)$ & $196(29)$ & $103(36)$ & $100(40)$ & $88(35)$ & $115(41)$ \\
\hline Histology: Non-small cell & $371(56)$ & $367(54)$ & $206(73)$ & $159(64)$ & $184(73)$ & $181(64)$ \\
\hline Small cell & $86(13)$ & $76(11)$ & $38(13)$ & $31(12)$ & $33(13)$ & $36(13)$ \\
\hline Missing & $207(31)$ & $243(35)$ & $39(14)$ & $60(24)$ & $34(14)$ & $65(23)$ \\
\hline \multicolumn{7}{|l|}{ Smoking status prior to cancer diagnosis } \\
\hline Non-smoker & $101(15.2)$ & $99(14)$ & $41(15)$ & $35(14)$ & $37(15)$ & $39(14)$ \\
\hline Ex-smoker & $331(50)$ & $324(47)$ & $143(51)$ & $121(48)$ & $127(51)$ & $137(49)$ \\
\hline Current smoker & $220(33)$ & $224(33)$ & $92(32)$ & $82(33)$ & $80(32)$ & $94(33)$ \\
\hline Missing & $12(2)$ & $39(6)$ & $7(2)$ & $12(5)$ & $7(3)$ & $12(4)$ \\
\hline \multicolumn{7}{|l|}{ Alcohol consumption prior to diagnosis } \\
\hline Never & $174(26)$ & $138(20)$ & $68(24)$ & $54(22)$ & $61(24)$ & $61(22)$ \\
\hline Ever & $449(68)$ & $466(68)$ & $198(70)$ & $171(68)$ & $175(70)$ & $194(69)$ \\
\hline Missing & $41(6)$ & $82(12)$ & $17(6)$ & $25(10)$ & $15(6)$ & $27(10)$ \\
\hline \multicolumn{7}{|c|}{ BMI $\left(\mathrm{kg} / \mathrm{m}^{2}\right)$ prior to diagnosis: mean (sd) } \\
\hline Underweight $(<18.5)$ & $11(2)$ & $20(3)$ & $4(1)$ & $8(3)$ & $4(2)$ & $8(3)$ \\
\hline Normal (18.5 to 25$)$ & $174(26)$ & $211(31)$ & $58(21)$ & $68(27)$ & $52(21)$ & $74(26)$ \\
\hline Overweight (25-30) & $236(36)$ & $239(35)$ & $103(36)$ & 95 (38) & $88(35)$ & 110 (39) \\
\hline Obese $(>30)$ & $219(33)$ & $156(23)$ & $106(38)$ & $67(27)$ & $96(38)$ & $77(27)$ \\
\hline Missing & $24(4)$ & $60(9)$ & $12(4)$ & $12(5)$ & $11(4)$ & $13(5)$ \\
\hline Deprivation fifth: $1^{\text {st }}$ (least deprived) & $102(15)$ & $102(15)$ & $52(18)$ & $36(14)$ & $45(18)$ & $43(15)$ \\
\hline $2^{\text {nd }}$ & $132(20)$ & $141(21)$ & $53(19)$ & $60(24)$ & $49(20)$ & $64(23)$ \\
\hline $3^{\text {rd }}$ & $120(18)$ & $143(21)$ & $50(18)$ & $52(21)$ & $44(18)$ & $58(21)$ \\
\hline $4^{\text {th }}$ & $150(23)$ & $154(23)$ & $57(20)$ & $50(20)$ & $49(20)$ & $58(21)$ \\
\hline $5^{\text {th }}$ (most deprived) & $158(24)$ & $144(21)$ & $68(24)$ & $51(20)$ & $61(24)$ & $58(21)$ \\
\hline Missing & $2(0)$ & $2(0)$ & $3(1)$ & $1(0)$ & $3(1)$ & $1(0)$ \\
\hline \multicolumn{7}{|l|}{ Comorbidity prior to cancer diagnosis } \\
\hline Cerebrovascular disease & $79(12)$ & $97(14)$ & $22(8)$ & $37(15)$ & $19(8)$ & $40(14)$ \\
\hline Chronic pulmonary disease & $174(26)$ & $199(29)$ & $68(24)$ & $81(32)$ & $64(26)$ & $85(30)$ \\
\hline Congestive heart disease & $60(9)$ & $80(12)$ & $16(6)$ & $26(10)$ & $13(5)$ & $29(10)$ \\
\hline Myocardial infarction & $103(16)$ & $106(16)$ & $36(13)$ & $38(15)$ & $34(14)$ & $40(14)$ \\
\hline Peptic ulcer disease & $49(7)$ & $53(8)$ & $24(9)$ & $19(8)$ & $18(7)$ & $25(9)$ \\
\hline Peripheral vascular disease & $129(19)$ & $115(17)$ & $43(15)$ & $35(14)$ & $39(16)$ & $39(14)$ \\
\hline Renal disease & $91(14)$ & $118(17)$ & $30(11)$ & $49(20)$ & $27(11)$ & $52(18)$ \\
\hline \multicolumn{7}{|l|}{ Other medication use after diagnosis } \\
\hline Low-dose aspirin use $\mathrm{d}^{\mathrm{d}}$ & $371(56)$ & $350(51)$ & $157(56)$ & $123(49)$ & $136(54)$ & $106(38)$ \\
\hline Statin use $\mathrm{d}^{\mathrm{d}}$ & $461(69)$ & $328(48)$ & $201(71)$ & $130(52)$ & $184(73)$ & $117(42)$ \\
\hline \multicolumn{7}{|l|}{ Anti-diabetic medication after diagnosis } \\
\hline Sulfonylureas ${ }^{\mathrm{d}}$ & $328(49)$ & $236(34)$ & $114(40)$ & $92(37)$ & $126(50)$ & $84(30)$ \\
\hline Insulin ${ }^{\mathrm{d}}$ & $80(12)$ & $102(15)$ & $27(10)$ & $46(18)$ & $41(16)$ & $51(18)$ \\
\hline Other ADDs ${ }^{d}$ & $94(14)$ & $30(4)$ & 37 (13) & $13(5)$ & $30(12)$ & $15(5)$ \\
\hline \multicolumn{7}{|l|}{ HbA1c level in year prior to diagnosis } \\
\hline$\leq 6.5 \%$ & $161(24)$ & $223(34)$ & $62(22)$ & $87(35)$ & $54(22)$ & $95(34)$ \\
\hline$>6.5 \%$ & $478(72)$ & $340(50)$ & $206(73)$ & $127(51)$ & $184(73)$ & $149(53)$ \\
\hline Missing & $25(4)$ & $113(17)$ & $15(5)$ & $36(14)$ & $13(5)$ & $38(14)$ \\
\hline
\end{tabular}

${ }^{a}$ Analysis includes lung cancer patients who have more than 1 year of records prior to diagnosis. ${ }^{\mathrm{b}}$ Analysis includes lung cancer patients who live more than 6 months after diagnosis. ${ }^{c}$ Excluding cancer patients from Thames Registry as surgery information not available. ${ }^{\mathrm{d}}$ Other medication use after diagnosis for metformin use after diagnosis columns, other medication use in year prior to diagnosis for metformin use in year prior to diagnosis columns. ADD= anti-diabetic drug 



\begin{tabular}{|c|c|c|c|c|c|c|c|c|c|c|}
\hline & \multicolumn{3}{|c|}{ Users } & \multicolumn{3}{|c|}{ Non-users } & \multirow[b]{2}{*}{$\begin{array}{l}\text { Unadjusted } \\
\text { HR (95\% CI) }\end{array}$} & \multirow[b]{2}{*}{$\boldsymbol{P}$} & \multirow[b]{2}{*}{$\begin{array}{c}\text { Adjusted } \\
\text { HR }(95 \% \text { CI })\end{array}$} & \multirow[b]{2}{*}{$\boldsymbol{P}$} \\
\hline & $\begin{array}{l}\text { Cancer- } \\
\text { specific } \\
\text { deaths }\end{array}$ & $\begin{array}{c}\text { All } \\
\text { patients }\end{array}$ & $\begin{array}{l}\text { Person } \\
\text { years }\end{array}$ & $\begin{array}{l}\text { Cancer- } \\
\text { specific } \\
\text { deaths }\end{array}$ & $\begin{array}{c}\text { All } \\
\text { patients }\end{array}$ & $\begin{array}{l}\text { Person } \\
\text { years }\end{array}$ & & & & \\
\hline ADD use after diagnosis ${ }^{\mathrm{a}, \mathrm{b}}$ & & & & & & & $(n=533)$ & & $(n=533)$ & \\
\hline Metformin use $\mathrm{c}^{\mathrm{C}}$ & 149 & 251 & 386 & 211 & 282 & 305 & $0.80(0.66-1.00)$ & 0.05 & $0.86(0.68-1.09)$ & 0.21 \\
\hline $\begin{array}{l}\text { Metformin use } 1-11 \text { prescriptions }^{\mathrm{d}} \\
\text { Metformin use } \geq 12 \text { prescriptions }^{\mathrm{d}}\end{array}$ & $\begin{array}{c}119 \\
30\end{array}$ & $\begin{array}{c}159 \\
92\end{array}$ & $\begin{array}{l}217 \\
169\end{array}$ & 211 & 282 & 305 & $\begin{array}{l}0.82(0.65-1.03) \\
0.75(0.47-1.17)\end{array}$ & $\begin{array}{l}0.09 \\
0.20\end{array}$ & $\begin{array}{l}0.87(0.68-1.11) \\
0.82(0.51-1.30)\end{array}$ & $\begin{array}{l}0.26 \\
0.40\end{array}$ \\
\hline $\begin{array}{l}\text { Metformin use } 1-365 \text { DDDs }^{\mathrm{d}} \\
\text { Metformin use } \geq 365 \text { DDDs }^{\mathrm{d}}\end{array}$ & $\begin{array}{c}121 \\
28\end{array}$ & $\begin{array}{l}172 \\
79\end{array}$ & $\begin{array}{l}236 \\
150\end{array}$ & 211 & 282 & 305 & $\begin{array}{l}0.79(0.63-0.99) \\
0.91(0.56-1.48)\end{array}$ & $\begin{array}{l}0.05 \\
0.71\end{array}$ & $\begin{array}{l}0.84(0.65-1.07) \\
1.01(0.62-1.67)\end{array}$ & $\begin{array}{l}0.16 \\
0.96\end{array}$ \\
\hline Sulfonylurea use $\mathrm{c}^{\mathrm{c}}$ & 132 & 210 & 278 & 228 & 323 & 412 & $1.10(0.88-1.37)$ & 0.42 & $1.10(0.87-1.40)$ & 0.41 \\
\hline Insulin use $\mathrm{c}^{\mathrm{c}}$ & 55 & 92 & 137 & 305 & 441 & 554 & $1.02(0.75-1.34)$ & 0.96 & $1.06(0.78-1.45)$ & 0.70 \\
\hline Other ADD use ${ }^{c}$ & 30 & 45 & 54 & 330 & 488 & 637 & $1.21(0.83-1.76)$ & 0.32 & $1.42(0.94-1.13)$ & 0.09 \\
\hline ADD use in year prior to diagnosis ${ }^{\mathrm{e}, \mathrm{f}}$ & & & & & & & $(n=1,350)$ & & $(n=1,350)$ & \\
\hline Metformin use & 514 & 664 & 536 & 558 & 686 & 505 & $0.89(0.79-1.00)$ & 0.06 & $0.97(0.86-1.11)$ & 0.67 \\
\hline $\begin{array}{l}\text { Metformin use } 1-11 \text { prescriptions } \\
\text { Metformin use } \geq 12 \text { prescriptions }\end{array}$ & $\begin{array}{l}375 \\
139\end{array}$ & $\begin{array}{l}483 \\
181\end{array}$ & $\begin{array}{l}403 \\
133\end{array}$ & 558 & 686 & 505 & $\begin{array}{l}0.88(0.77-1.00) \\
0.92(0.76-1.11)\end{array}$ & $\begin{array}{l}0.05 \\
0.38\end{array}$ & $\begin{array}{l}0.95(0.83-1.10) \\
1.03(0.85-1.25)\end{array}$ & $\begin{array}{l}0.51 \\
0.77\end{array}$ \\
\hline $\begin{array}{l}\text { Metformin use } 1-365 \text { DDDs } \\
\text { Metformin use } \geq 365 \text { DDDs }\end{array}$ & $\begin{array}{c}455 \\
59\end{array}$ & $\begin{array}{c}577 \\
87\end{array}$ & $\begin{array}{c}467 \\
69\end{array}$ & 558 & 686 & 505 & $\begin{array}{l}0.91(0.80-1.02) \\
0.78(0.60-1.02)\end{array}$ & $\begin{array}{l}0.12 \\
0.07\end{array}$ & $\begin{array}{l}0.98(0.86-1.12) \\
0.90(0.68-1.19)\end{array}$ & $\begin{array}{l}0.78 \\
0.47\end{array}$ \\
\hline Sulfonylurea use & 453 & 564 & 389 & 619 & 786 & 651 & $1.11(0.99-1.26)$ & 0.08 & $1.07(0.94-1.21)$ & 0.31 \\
\hline Insulin use & 143 & 182 & 148 & 929 & 1,168 & 892 & $0.93(0.78-1.11)$ & 0.40 & $1.00(0.84-1.21)$ & 0.97 \\
\hline Other ADD use & 99 & 124 & 103 & 973 & 1,226 & 938 & $0.91(0.74-1.13)$ & 0.40 & $0.98(0.79-1.21)$ & 0.84 \\
\hline
\end{tabular}

a Analysis includes lung cancer patients who live more than 6 months after diagnosis

b Adjusted analyses controlled for year of diagnosis, age at diagnosis, sex, radiotherapy within 6 months, chemotherapy within 6 months, comorbidities (prior to diagnosis, including cerebrovascular disease, chronic pulmonary disease, congestive heart disease, diabetes, myocardial infarction, peptic ulcer disease, peripheral vascular disease, renal disease), other anti-diabetic medication use (after diagnosis, as time varying covariates, including metformin, sulfonylureas, insulin and other ADDs), other medication use (after diagnosis, as time varying covariates, specifically low-dose aspirin and statins) and deprivation (in fifths).

${ }^{c}$ Medication use modelled as a time varying covariate with an individual considered a non-user prior to 6 months after first medication usage and a user after this time, excludes deaths in the first 6 months after cancer diagnosis.

${ }^{\mathrm{d}}$ Medication use modelled as a time varying covariate with an individual considered a non-user prior to 6 months after first medication usage, a user of 0 to 12 prescriptions from 6 months after

first prescription to 6 months after $12^{\text {th }}$ prescription (or 365 DDDs) and a greater user after this time, excludes deaths in the 6 months after cancer diagnosis.

${ }^{\mathrm{e}}$ Analysis includes lung cancer patients who have more than 1 year of records prior to diagnosis 
${ }_{\mathrm{f}}^{\mathrm{f}}$ Adjusted analyses controlled for year of diagnosis, age at diagnosis, sex, comorbidities (prior to diagnosis, including cerebrovascular disease, chronic pulmonary disease, congestive heart disease, diabetes, myocardial infarction, peptic ulcer disease, peripheral vascular disease, renal disease), other anti-diabetic medication use (in year prior to diagnosis, including metformin, sulfonylureas, insulin and other ADDs), other medication use (in year prior to diagnosis, specifically low-dose aspirin and statins) and deprivation (in fifths).

$\mathrm{ADD}=$ anti-diabetic drug 